The Research Journal of the Costume Culture

[Original Article]

Received January 10, 2017

Revised April 01, 2017

Accepted April 18, 2017

${ }^{\dagger}$ Corresponding author

(skyokwon@howon.ac.kr)

ORCID

Soon Kyo Kwon

http://orcid.org/0000-0003-1940-5553

Mi-kyung Uh

http://orcid.org/0000-0003-0557-1657

This work was supported by a research grant from Howon University.

This paper is a part of a doctoral dissertation.
pISSN 1226-0401

Development of a basic kimono sleeve

- Focusing on the standard body type of

Korean people in their thirties -

\author{
Soon Kyo Kwon ${ }^{\dagger}$ and Mi-Kyung $\mathrm{Uh}^{*}$
}

Dept. of Fashion Design, Howon University, Korea

Dept. of Clothing and Textiles, Hanyang University, Korea ${ }^{*}$

\section{기모노슬리브 원형 개발 \\ - 30대 표준체형을 중심으로 -}

권 순 교 ${ }^{\dagger} \cdot$ 어 미 경

호원대학교 패션디자인학과, 한양대학교 의류학과 ${ }^{*}$

\begin{abstract}
Kimono sleeves have continuously appeared in modern fashion as a design motif and this trend has become increasingly prevalent recently. However for research in the area of clothing composition for kimono sleeves in Korea, there has been a lack of development of master patterns based on basic data from the analysis of the standard body type of Korean people and finalized designs based on comparative experiments and analysis of pre-existing research Thus, there is no ideal master kimono sleeve pattern development research based on the examination of the results of the analysis of the standard body type of Korean people. Therefore by recognizing the importance of developing a master kimono sleeve pattern, this research aims to present a practical master kimono sleeve pattern for the standard body type of someone in their $30 \mathrm{~s}$. First, the four master patterns were collected and a dressing evaluation was conducted, and by selecting and improving one of these master designs, a final research master pattern was developed after a second dressing evaluation. Through this research, it was possible to design a master kimono sleeve pattern appropriate both externally and functionally for the standard body type of someone in their 30s, which has not been a consideration in previous research.
\end{abstract}

Keywords: kimono sleeve(기모노슬리브), basic pattern(원형 패턴), appearance evaluation(외관 평가), mobility evaluation(동작 평가)

\section{Introduction}

기모노슬리브는 현대패션에서 디자인 모티브로 지속적으로 나타나고 있고, 최근 그러한 경향이 높아지고 있다. 기모노슬리브는 바디스와 슬리브를 연결하는 암홀 
솔기선 없이 직선으로 이어진 형으로 어깨 관절에 의 해 다양한 운동을 하는 팔부위의 특성으로 인해 슬리 브 각도가 커지면 가동성은 좋으나 바로 선 자세에서 생기는 주름으로 인해 심미성은 떨어지게 되므로 패 턴설계 시 외관과 기능성을 동시에 고려해야 한다. 그럼에도 불구하고 기모노슬리브에 대한 선행 연구 모두 기모노슬리브의 소매 각도와 거싯을 중심으로 한 동작적합성 연구(Cho, 1993; Hong, 2003; Kim, 1983; Kim, 1988; Kim, 1996; Kwon, Jeong, \& Park, 2013)에 국한되어 있으며, 해외에서 개발된 기모노슬 리브 원형을 국내 연구에 그대로 활용하거나 일본문 화식 원형을 기본으로 한 절충식 패턴인 임원자식 기 모노슬리브 원형을 적용하여 연구하는 등 국내 체형 에 적합한 기모노슬리브 원형 개발에 대한 연구는 전 무한 것으로 나타났으며, 이에 연구의 필요성이 요구 된다. 또한 30 대가 여성의류 시장의 소비 주체로 부 상하는 점을 감안하여 패션에 대한 전문지식을 갖추 고, 가치소비를 지향하는 국내 30 대를 위한 외관과 기능을 동시에 만족시키는 이상적인 기모노슬리브 원형을 개발하는데 그 목적이 있다.

\section{Development}

\section{Selecting master patterns}

수집원형 선정에 앞서 30 대 표준체형을 분류하여 피험자를 선정하였다. 기술표준원(Size Korea)의 표 준체형 선정 절차에 따르면 표준체형(standard body type)이란 학문적으로 다빈도 구간에 속하면서 아름 다운 크기와 형태, 프로포션을 갖는 체형으로 정의하 고 있으며, 평균체형(average body type)이란 신체 각 부위에 산술평균치(Mean)가 적용된 체형으로 정의하 고 있다(Size Korea, n.d.). 따라서 표준체형은 평균체 형의 개념에 미적 판단기준이 첨가된 것으로 기준이 나 근거가 되는 일반적인 체형을 의미하며, 본 연구 에서는 30 대 표준체형을 기준으로 패턴 개발을 하고 자 한다. 표준체형 분류를 위한 분석데이터는 기술표 준원 제6차 한국인 인체치수 직접측정 조사사업 보고 서 결과를 토대로 30 39세 여성 690명의 인체치수 데이터를 추출한 평균값을 활용하였다. 피험자는 30 39세의 표준체형 측정 항목 평균값에 해당하는 3 명 을 선정하였다. 측정항목은 높이항목 6 개, 둘레항목 9
개, 길이항목 14 개, 각도항목 2 개, 드롭치항목 2 개 총 33 개 항목으로 하였다. 수집원형은 국내·외 단행본 과 번역본 중 패턴 전개 내용이 비교적 자세하고 정 확하며 국내에서 교육용으로 가장 많이 활용되고 있 는 절충식 2개 패턴 김경순식(Kim, 1998), 임원자식 (Im, 2003)과 단촌식 2개 패턴 암스트롱식(Armstrong, 2010), 콥식(Kopp, Rolfo, Zelin, \& Gross, 1991, 1992)을 선행 원형으로 선정하였다. 4개 패턴의 특성 은 다음과 같다.

수집원형 패턴 상의원형 설계식을 보면 김경순, 임 원자 패턴의 경우, 가슴둘레의 여유분, 목너비, 목깊 이, 어깨경사 그리고 앞처짐분량에서 차이를 보이며, 나머지 설계식은 유사한 방법으로 전개되었다. 암스 트롱, 콥 패턴의 경우, 실측치를 중심으로 한 설계방 법은 유사하였으나, 둘레 부위의 여유분, 겨드랑앞벽 사이길이 등 많은 항목에서 차이를 보였고, 콥의 경 우 목너비와 목깊이는 수록된 곡자(neckline curve)를 활용하여 전개하도록 하고 있다. 특히 암스트롱 패턴 은 인체 측정 항목이 다른 3 개 패턴과 큰 차이를 보 였고, 측정 항목의 수도 많아 세심한 측정이 요구되 었다.

소매원형 설계식을 보면 임원자 패턴의 경우, 위팔 둘레, 팔꿈치둘레를 상의원형 진동둘레 치수를 적용 해 설정하고, 콥 패턴은 실제 측정한 치수를 적용한다.

기모노슬리브 설계식의 경우, 김경순, 암스트롱 패 턴은 완성된 상의원형 패턴에 소매 패턴 설계를 추가 하여 전개하고, 임원자, 콥 패턴은 완성된 상의원형 패턴과 소매원형 패턴을 동시에 놓고 전개한다. 소매 각도에 있어서 임원자, 암스트롱 패턴은 어깨가쪽점 에 여유분을 주어 겨드랑이 부위의 여유분을 추가하 였다.

\section{Appearance evaluation and mobility evaluation}

수집원형에 대한 외관평가는 의복구성분야의 전문 적 지식과 강의 경험이 있는 석사 이상의 전공자 8 명 으로 구성하였으며, 피험자 3 명이 4 벌의 수집원형 실 험복을 착의하고, 3 회 반복 평가하였다. 평가항목은 전면, 측면, 후면 총 30 항목으로 구성하였다. 평가항 목은 전면 12항목(앞목깊이는 적당한가? 앞목너비는 적당한가? 앞몸판 겨드랑 부위의 여유분은 적당한가? 암홀깊이는 적당한가? 소매안쪽솔기선은 제 위치에 
있는가? 젖가슴둘레선은 제 위치에 있는가? 젖가슴둘 레 부위의 여유분은 적당한가? 허리둘레선은 제 위치 에 있는가? 허리둘레 부위의 여유분은 적당한가? BP 의 위치는 적당한가? 허리다트의 위치는 적당한가? 허리다트의 길이는 적당한가?), 측면 10 항목(어깨솔 기선은 제 위치에 있는가? 소매 윗솔기선은 팔의 중 앙을 따라 위치하는가? 위팔둘레선은 제 위치에 있는 가? 위팔둘레 부위의 여유분은 적당한가? 팔꿈치둘레 선은 제 위치에 있는가? 팔꿈치둘레선은 제 위치에 있는가? 팔꿈치둘레 부위의 여유분은 적당한가? 손목 둘레 부위의 여유분은 적당한가? 허리둘레선은 수평 인가? 팔길이는 적당한가? 옆솔기선의 위치는 적당한 가?), 후면 8항목(뒷목둘레의 맞음새는 적당한가? 뒷 목깊이는 적당한가? 뒤품 부위의 여유분은 적당한가? 젖가슴둘레 부위의 여유분은 적당한가? 허리둘레선 은 제 위치에 있는가? 허리둘레 부위의 여유분은 적 당한가? 허리다트의 위치는 적당한가? 허리다트의 길 이는 적당한가?)으로 나누어 평가하였다.

동작평가는 피험자 3 명이 4 벌의 수집원형 실험복 을 착의하고 3 회 반복 평가하였다. 평가항목은 정립 시와 동작 시로 나누어 총 45 항목으로 구성하였다. 정립 시 10 항목(목둘레부위의 착용감은 어떠한가? 어 깨부위의 착용감은 어떠한가? 앞품부위의 착용감은 어떠한가? 뒤품부위의 착용감은 어떠한가? 겨드랑이 부위의 착용감은 어떠한가? 젖가슴둘레 부위의 착용 감은 어떠한가? 허리둘레 부위의 착용감은 어떠한가? 위팔둘레 부위의 착용감은 어떠한가? 팔꿈치둘레 부 위의 착용감은 어떠한가? 손목둘레 부위의 착용감은 어떠한가?)이며, 동작평가는 팔을 앞으로 $45^{\circ}$ 들었을 때, 팔을 앞으로 $90^{\circ}$ 들었을 때, 팔을 옆으로 $45^{\circ}$ 들 었을 때, 팔을 옆으로 $90^{\circ}$ 들었을 때, 걸을 때로 나누 어 평가하였고, 35 항목(어깨 부위의 착용감은 어떠한 가? 겨드랑이 부위의 착용감은 어떠한가? 젖가슴둘레 부위의 착용감은 어떠한가? 허리둘레 부위의 착용감
은 어떠한가? 위팔둘레 부위의 착용감은 어떠한가? 팔꿈치둘레 부위의 착용감은 어떠한가? 손목둘레 부 위의 착용감은 어떠한가?)으로 나누어 평가하였다.

자료처리 및 분석은 IBM SPSS Statistics V.20을 이용하여 분산분석과 $t$-test로 통계분석하고, 통계적 으로 유의미한 차이가 있는 항목에 대해 던컨의 사후 분석(Duncan's post-hoc analysis)을 통해 평균 간에 유의한 차이를 검증하였다. 평가방법은 각각의 문항 에 대해 리커트 5점 척도(Likert scale)를 사용하였다. 평가에 사용된 실험복 소재는 머슬린(muslin)으로 하 였으며, 그 물리적 특성은 〈Table 1〉과 같다.

수집원형의 착의평가 결과, 외관평가 전체 항목의 평균은 암스트롱이 3.08 , 임원자 2.89 , 김경순 2.76 , 콥 2.58 의 순으로 나타났으며, 전면, 측면, 후면 모든 항목에서 통계적으로 유의미한 차이를 보였다 $(p<.001)$ (Fig. 3, Table 2).

수집원형의 동작평가 전체 항목의 평균은 암스트 롱이 4.15점으로 가장 높았고, 다음으로 임원자 3.56 점, 김경순 2.81점, 콥 2.50점 순으로 나타났으며, 통 계적으로 유의미한 차이가 있는 것으로 나타났다 $(p<$ .001)(Fig. 4, Table 3). 이상의 외관평가와 동작평가 분석결과, 암스트롱 원형의 평균값이 가장 높게 나타 났음을 알 수 있다. 평균값이 가장 높게 나타난 암스

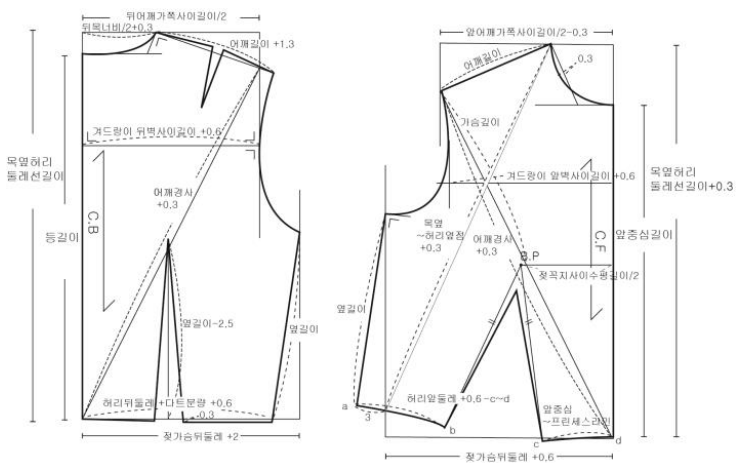

<Fig. 1> Basic bodice of Helen Joseph-Armstrong

$<$ Table 1> Physical characteristics of fabric

\begin{tabular}{|c|c|c|c|c|c|c|c|}
\hline $\begin{array}{l}\text { Fibrous } \\
\text { tissue }\end{array}$ & $\begin{array}{l}\text { Fiber mixture } \\
\text { rate }(\%)\end{array}$ & $\begin{array}{l}\text { Thickness } \\
(\mathrm{mm})\end{array}$ & \multicolumn{2}{|c|}{$\begin{array}{c}\text { Density } \\
(\mathrm{stand} / 5.0 \mathrm{~cm})\end{array}$} & $\begin{array}{l}\text { Mass } \\
\left(\mathrm{g} / \mathrm{m}^{2}\right)\end{array}$ & \multicolumn{2}{|c|}{$\begin{array}{l}\text { Tensile strength } \\
\text { (N) }\end{array}$} \\
\hline \multirow{2}{*}{ Plain weave } & \multirow{2}{*}{ Cotton 100} & \multirow{2}{*}{0.28} & Warp & Weft & \multirow{2}{*}{114.8} & Warp & Weft \\
\hline & & & 134.6 & 132.2 & & 250 & 250 \\
\hline
\end{tabular}


<Table 2> Results of appearance evaluation

\begin{tabular}{|c|c|c|c|c|c|c|}
\hline \multirow{2}{*}{ Evaluation items } & \multicolumn{4}{|c|}{4 master patterns $M(S D)$} & \multirow{2}{*}{$F$-value } & \multirow{2}{*}{$\begin{array}{l}\text { Duncan's } \\
\text { post-hoc }\end{array}$} \\
\hline & $\mathrm{Kim}^{\mathrm{A}}$ & $\operatorname{Im}^{\mathrm{B}}$ & Armstrong $^{\mathrm{C}}$ & $\mathrm{Kopp}^{\mathrm{D}}$ & & \\
\hline \multirow{2}{*}{ Front } & 2.86 & 3.06 & 3.29 & 2.82 & \multirow{2}{*}{$17.441^{* * *}$} & \multirow{2}{*}{$\mathrm{DA}<\mathrm{B}<\mathrm{C}$} \\
\hline & $(0.410)$ & $(0.461)$ & $(0.487)$ & $(0.409)$ & & \\
\hline \multirow{2}{*}{ Side } & 2.67 & 2.68 & 2.89 & 2.15 & \multirow{2}{*}{$27.644^{* * *}$} & \multirow{2}{*}{$\mathrm{D}<\mathrm{AB}<\mathrm{C}$} \\
\hline & $(0.491)$ & $(0.499)$ & $(0.586)$ & $(0.448)$ & & \\
\hline \multirow{2}{*}{ Back } & 2.71 & 2.89 & 3.00 & 2.77 & \multirow{2}{*}{$6.037^{* * *}$} & \multirow{2}{*}{$\mathrm{AD}<\mathrm{DB}<\mathrm{BC}$} \\
\hline & $(0.410)$ & $(0.401)$ & $(0.581)$ & $(0.349)$ & & \\
\hline \multirow{2}{*}{ Whole average } & 2.76 & 2.89 & 3.08 & 2.58 & \multirow{2}{*}{$23.495^{* * *}$} & \multirow{2}{*}{$\mathrm{D}<\mathrm{A}<\mathrm{B}<\mathrm{C}$} \\
\hline & $(0.343)$ & $(0.342)$ & $(0.468)$ & $(0.298)$ & & \\
\hline
\end{tabular}

${ }^{*} p<.05, \quad{ }^{* *} p<.01,{ }^{* * *} p<.001$

트롱 원형을 연구원형 패턴으로 선정하였다(Fig. 1, Fig. 2).

\section{Development of a basic kimono sleeve}

외관평가 결과, 암스트롱 패턴은 전면 허리둘레선 의 수평, 측면 위팔둘레 부위의 여유분, 팔꿈치둘레선 의 위치, 팔꿈치둘레선의 여유분, 팔길이, 후면 목둘 레선의 맞음새, 목깊이, 젖가슴둘레선의 여유분, 허리 둘레선의 여유분 총 9 개 항목을 제외한 21개 항목에 서 가장 높은 것으로 나타났다. 동작평가 결과에서는 45 개 모든 항목에서 가장 높게 나타났다. 또한 정립 시 목둘레 부위, 어깨 부위, 겨드랑이 부위, 팔을 앞으 로 $45^{\circ}$ 들었을 때 겨드랑이 부위, 팔을 앞으로 $90^{\circ}$ 들었을 때 겨드랑이 부위, 걸을 때 겨드랑이 부위의 6 개 항목을 제외한 39 개 항목에서 4.0점 이상으로 높 게 나타났다. 따라서 암스트롱 패턴을 연구원형 패턴 으로 선정하고, 수정, 보완하여 최종연구원형 패턴을 개발하였다.

\section{1) Drafting patterns}

최종연구원형 패턴설계 시 필요치수 항목은 목옆 젖꼭지길이, 목밑둘레, 소매산길이, 위팔둘레, 팔안쪽 길이가 추가된 젖가슴둘레, 등길이, 겨드랑앞(뒤)벽사 이길이, 어깨가쪽사이길이(앞, 뒤), 젖꼭지사이수평길 이, 앞중심길이, 목옆어깨뼈아래허리둘레선길이, 허 리둘레, 다트 위치(앞,뒤), 뒤목, 옆길이, 어깨길이, 어
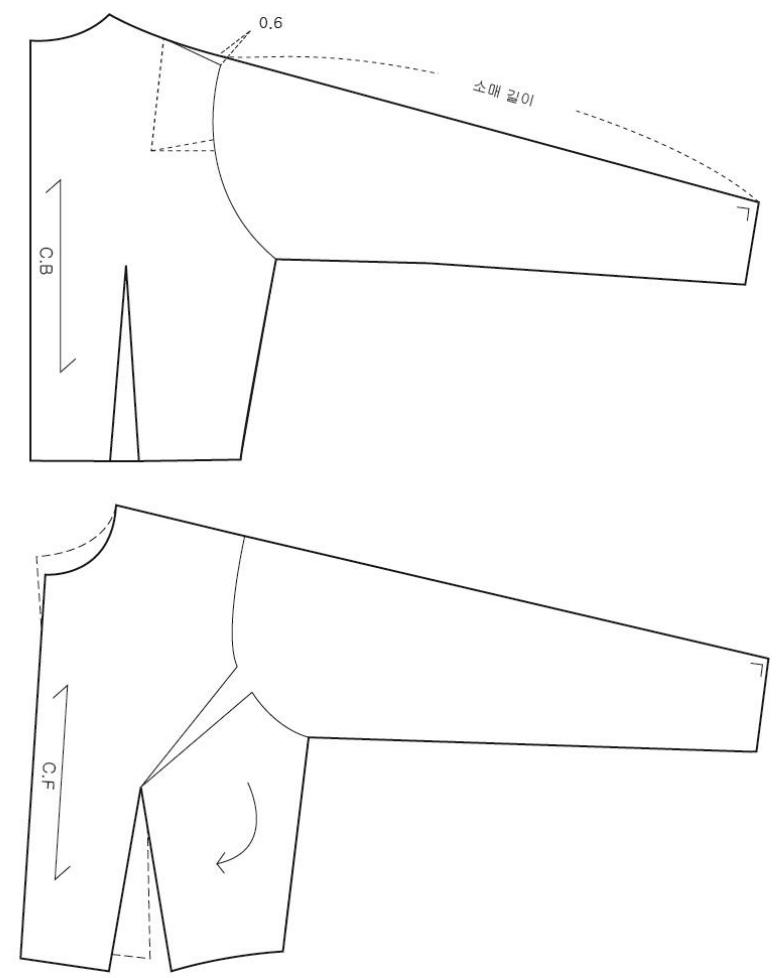

<Fig. 2> Basic kimono sleeve of Helen Joseph-Armstrong

깨경사(좌우), 가슴깊이, 목옆점 허리옆점, 팔길이, 손 목둘레이다. 1 차 착의평가에서 선정된 연구원형을 바 탕으로 수정, 보완된 최종연구원형 패턴의 설계식은 〈Table 4〉와 같고, 최종연구원형 패턴 개발과정에서 수정, 보완된 사항은 다음과 같다. 


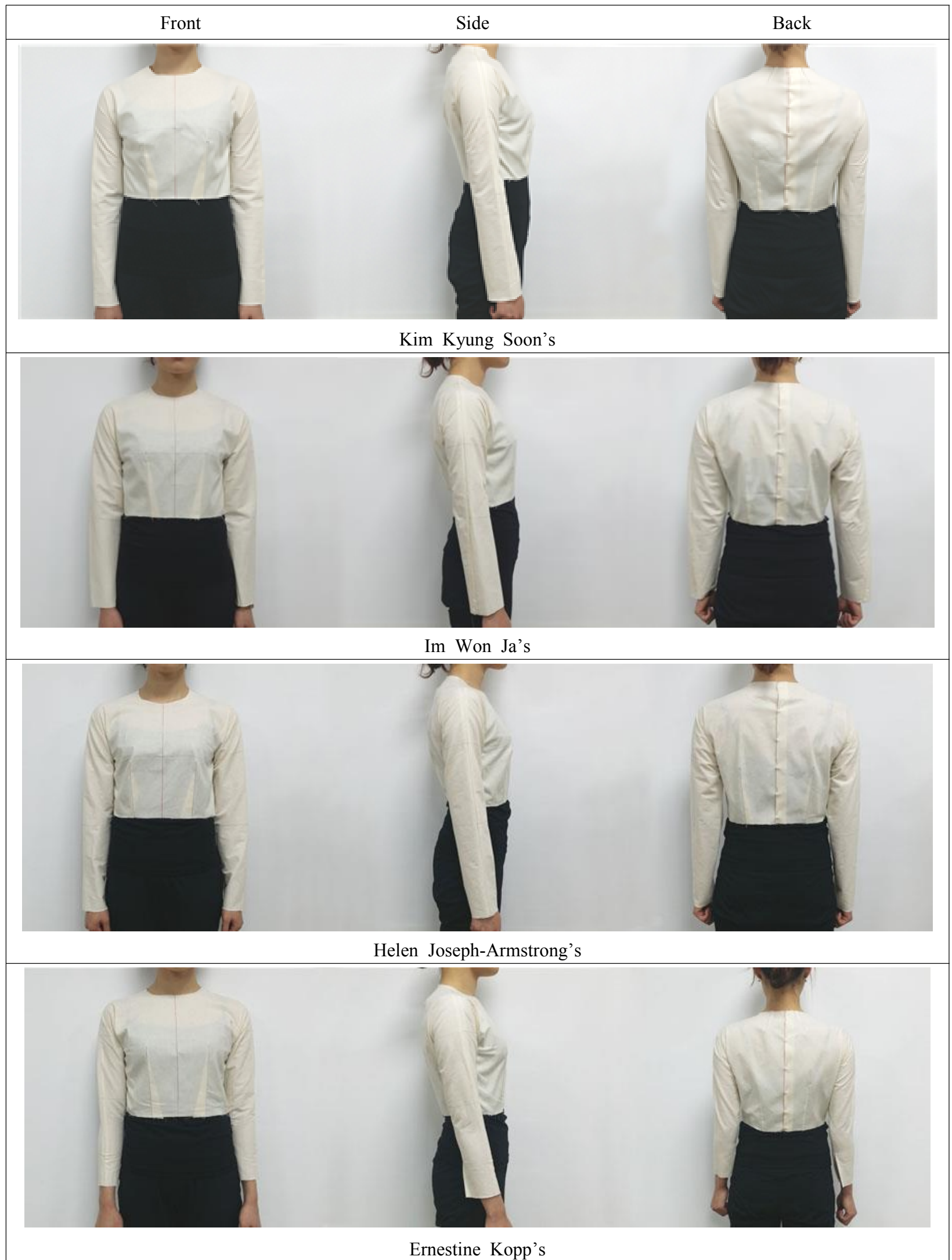

<Fig. 3> Appearance evaluation 


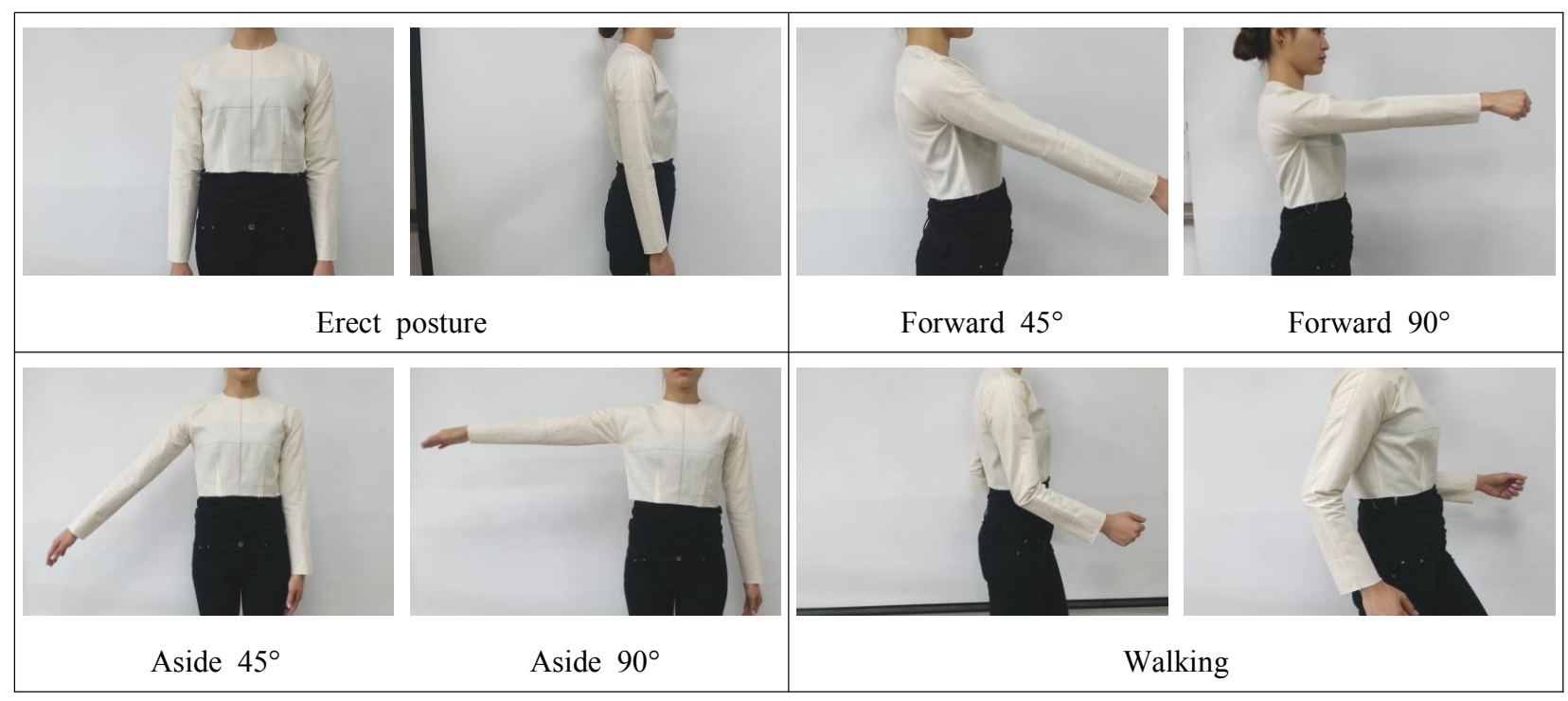

<Fig. 4> Mobility evaluation

$<$ Table 3> Results of mobility evaluation

\begin{tabular}{|c|c|c|c|c|c|c|}
\hline \multirow{2}{*}{ Evaluation items } & \multicolumn{4}{|c|}{4 master patterns $M(S D)$} & \multirow{2}{*}{$F$-value } & \multirow{2}{*}{$\begin{array}{l}\text { Duncan's } \\
\text { post-hoc }\end{array}$} \\
\hline & $\operatorname{Kim}^{\mathrm{A}}$ & $\operatorname{Im}^{B}$ & Armstrong $^{\mathrm{C}}$ & Kopp $^{\mathrm{D}}$ & & \\
\hline \multirow{2}{*}{ Erect posture } & 2.69 & 3.37 & 4.10 & 2.31 & \multirow{2}{*}{$12.359^{* * *}$} & \multirow{2}{*}{$\mathrm{DA}<\mathrm{B}<\mathrm{C}$} \\
\hline & $(0.242)$ & $(0.981)$ & $(0.608)$ & $(0.645)$ & & \\
\hline \multirow{2}{*}{ Forward $45^{\circ}$} & 2.65 & 3.48 & 4.14 & 2.44 & \multirow{2}{*}{$18.976^{* * *}$} & \multirow{2}{*}{$\mathrm{DA}<\mathrm{B}<\mathrm{C}$} \\
\hline & $(0.358)$ & $(0.842)$ & $(0.429)$ & $(0.374)$ & & \\
\hline \multirow{2}{*}{ Forward $90^{\circ}$} & 2.76 & 3.35 & 4.25 & 2.29 & \multirow{2}{*}{$29.154^{* * *}$} & \multirow{2}{*}{$\mathrm{D}<\mathrm{A}<\mathrm{B}<\mathrm{C}$} \\
\hline & $(0.311)$ & $(0.780)$ & $(0.383)$ & $(0.189)$ & & \\
\hline \multirow{2}{*}{ Aside $45^{\circ}$} & 3.11 & 3.95 & 4.29 & 2.90 & \multirow{2}{*}{$11.738^{* * *}$} & \multirow{2}{*}{$\mathrm{DA}<\mathrm{BC}$} \\
\hline & $(0.370)$ & $(0.869)$ & $(0.539)$ & $(0.398)$ & & \\
\hline \multirow{2}{*}{ Aside $90^{\circ}$} & 2.67 & 3.86 & 4.24 & 2.81 & \multirow{2}{*}{$18.791^{* * *}$} & \multirow{2}{*}{$\mathrm{AD}<\mathrm{BC}$} \\
\hline & $(0.071)$ & $(0.811)$ & $(0.585)$ & $(0.378)$ & & \\
\hline \multirow{2}{*}{ Walking } & 3.02 & 3.43 & 3.90 & 2.33 & \multirow{2}{*}{$6.119^{* *}$} & \multirow{2}{*}{$\mathrm{DA}<\mathrm{AB}<\mathrm{BC}$} \\
\hline & $(0.367)$ & $(1.180)$ & $(0.929)$ & $(0.468)$ & & \\
\hline \multirow{2}{*}{ Whole average } & 2.81 & 3.56 & 4.15 & 2.50 & \multirow{2}{*}{$15.449^{* * *}$} & \multirow{2}{*}{$\mathrm{DA}<\mathrm{B}<\mathrm{C}$} \\
\hline & $(0.231)$ & $(0.893)$ & $(0.571)$ & $(0.339)$ & & \\
\hline
\end{tabular}

${ }^{*} p<.05,{ }^{* *} p<.01, \quad{ }^{* * *} p<.001$

첫째, 연구원형의 외관평가 결과, 목깊이 항목은 2.94점, 목너비 항목은 3.06점이며, 동작평가 결과, 목 둘레 부위 항목은 3.56점으로 외관평가와 동작평가에 서 다른 3 개 원형보다 높은 점수를 받았으나, 다른 항
목에 비해 낮은 점수를 나타냈다. 또, 동작평가 시 목 둘레부위가 타이트하여 답답하게 느낀다는 피험자의 주관적 의견도 있었다. 따라서 앞목 너비 약 $0.5 \mathrm{~cm}$, 앞목 깊이 약 $1 \mathrm{~cm}$ 로 늘려주었고, 뒷목너비는 앞목 너 
<Table 4> Comparison of the drafting the research basic kimono sleeve and the final research basic kimono sleeve

\begin{tabular}{|c|c|c|c|}
\hline \multicolumn{2}{|l|}{ Division } & Research basic bodice & Final research basic bodice \\
\hline \multicolumn{2}{|l|}{ Waist back length } & Measurement value & Measurement value \\
\hline \multicolumn{2}{|l|}{ Bust circumference } & Bust circumference $/ 2+2.6$ & Bust circumference $/ 2+2.6$ \\
\hline \multicolumn{2}{|c|}{ Waist circumference } & Waist circumference $/ 2+1.2$ & Waist circumference $/ 2+1.2$ \\
\hline \multicolumn{2}{|l|}{ Interscye, front } & Interscye, front $/ 2$ & Interscye, front $/ 2$ \\
\hline \multicolumn{2}{|l|}{ Interscye, back } & Interscye, back $/ 2+0.6$ & Interscye, back $/ 2+0.6$ \\
\hline \multirow{2}{*}{ Neck breadth } & Front & Neck shoulder point $\sim$ center front & Neck base circumference $/ 6+0.5$ \\
\hline & Back & Neck breadth $/ 2+0.3$ & Neck base circumference $/ 6+0.5$ \\
\hline \multirow{2}{*}{ Neck depth } & Front & $\begin{array}{l}\text { Neck shoulder point to waist, } \\
\text { parallel-waist front length }\end{array}$ & Neck base circumference/ $6+1$ \\
\hline & Back & $\begin{array}{l}\text { Shoulder tip to center line at waist } \\
\text {-waist back length }\end{array}$ & $2.3 \mathrm{~cm}$ \\
\hline \multirow{2}{*}{ Shoulder angle } & Front & Measurement value +0.3 & Measurement value \\
\hline & Back & Measurement value +0.3 & Measurement value +0.3 \\
\hline \multirow{2}{*}{ Posterior shoulder length } & Front & Posterior shoulder length/2-0.3 & Posterior shoulder length $/ 2-0.3$ \\
\hline & Back & Posterior shoulder length/2 & Posterior shoulder length/2 \\
\hline \multicolumn{2}{|l|}{ Shoulder length } & Measurement value & Measurement value \\
\hline \multicolumn{2}{|c|}{ Neck shoulder point to bust point } & Measurement value & Measurement value \\
\hline \multicolumn{2}{|c|}{ Bust point $\sim$ bust point } & Measurement value & Measurement value \\
\hline \multicolumn{2}{|c|}{$\begin{array}{c}\text { Neck shoulder point to corner } \\
\text { of side waist }\end{array}$} & Measurement value +0.3 & Measurement value +0.3 \\
\hline \multicolumn{2}{|l|}{ Waist front length } & Measurement value & Measurement value \\
\hline \multicolumn{2}{|l|}{ Side length } & Measurement value & Measurement value +1 \\
\hline \multicolumn{2}{|c|}{ Wrist circumference } & Wrist circumference/2 & Wrist circumference $/ 2 \pm 0.5$ \\
\hline \multirow{2}{*}{ Darts length } & Front & Bust point -1.6 & Bust point -1.6 \\
\hline & Back & Side length & Side length \\
\hline
\end{tabular}

비에 맞추어 수정하였다.

둘째, 연구원형의 어깨가쪽점의 경우, 중심에 위치 할 수 있도록 어깨경사 +0.3 의 설계식에서 0.3 의 여유 분을 제외한 어깨경사길이만을 적용하여 수정하였다. 셋째, 연구원형은 치수 측정 시 어깨가쪽점에서 젖 꼭지점을 연결하는 길이를 통해 설계 시 젖꼭지점이 결정되므로 그 정확도가 떨어진다. 따라서 목옆젖꼭 지길이를 필요치수 항목으로 적용함에 따라 목옆젖 꼭지길이를 $0.5 \sim 1 \mathrm{~cm}$ 늘려주어 가슴둘레선이 제 위치
에 오도록 수정하였다.

넷째, 연구원형의 겨드랑이 부위는 팔을 옆으로 들 었을 때를 제외하고는 모든 항목에서 3 점대의 점수를 받았다. 따라서 옆길이를 $1 \mathrm{~cm}$ 늘려주어 겨드랑점에 가깝게 하여 착용감이 향상되도록 하였다. 또한 위팔 둘레 부위의 여유분이 많아 2.35점의 낮은 점수를 나 타냈던 연구원형의 위팔둘레가 약 $1.5 \mathrm{~cm}$ 줄어들어 착용감 향상과 동시에 위팔둘레 부위의 외관을 향상 시킬 수 있도록 하였다. 
다섯째, 손목둘레 부위의 소매윗솔기선의 위치가 평가항목에는 구체적으로 구분되어 있지 않지만, 외 관평가결과, 앞쪽으로 위치한다는 평가자들의 언급을 반영하여 $0.5 \mathrm{~cm}$ 뒤쪽으로 위치하도록 수정하였다.

\section{(1) Drafting the basic bodice}

Front

(1) $\mathrm{A} \mathrm{B}$ : 목옆점에서 허리둘레선길이 $+0.3 \mathrm{~cm}$ 의 선 을 그린다.

(2) $\mathrm{A} \sim \mathrm{C}:$ 어깨가쪽사이길이 $/ 2 \sim 0.3 \mathrm{~cm}$ 의 선을 그린 다. $\mathrm{C}$ 에서 약 $8 \mathrm{~cm}$ 의 수직선을 그린다.

(3) B D: 앞젖가슴둘레 $/ 2+0.6$ 의 선을 그린다. $\mathrm{D}$ 에 서 약 $28 \mathrm{~cm}$ 의 수직선을 그린다.

(4) $\mathrm{A} \sim \mathrm{E}$ : 목밑둘레 $/ 6+1 \mathrm{~cm}$

(5) $\mathrm{A} \sim \mathrm{F}$ : 목밑둘레 $/ 6+0.5 \mathrm{~cm}$

(6) $\mathrm{E}, \mathrm{F}$ 에서 시작하는 직각선을 그린다. $\mathrm{G} \mathrm{A}$ 를 3 등분하고, 아래에서 $1 / 3$ 점에서 $0.5 \mathrm{~cm}$ 내린 점을 지나면서 $\mathrm{E}, \mathrm{F}$ 와 연결되는 곡선을 그린다.

(7) $\mathrm{B} \sim \mathrm{H}$ : 어깨경사 $+0.3 \mathrm{~cm}$ 의 선을 그린다. $\mathrm{H} \sim \mathrm{F}$ 는 어깨길이가 된다.

(8) $\mathrm{F} \sim \mathrm{I}, \mathrm{J} \sim \mathrm{I}$ : 목옆점에서 젖꼭지길이와 젖꼭지사이 수평길이 $/ 2$ 가 만나는 I가 B.P.가 된다. 앞중심선 과 직각으로 $\mathrm{I}$ 를 지나는 선이 젖가슴둘레선이 된다.

(9) $\mathrm{K}: \mathrm{E} \sim \mathrm{J}$ 를 2 등분하여 겨드랑앞벽사이길이 $/ 2+$ $0.6 \mathrm{~cm}$ 의 수평선을 그리고, $\mathrm{L}$ 표기 후 $10 \mathrm{~cm}$ 의 가 이드라인을 수직으로 그린다.

(10) $\mathrm{F} \mathrm{M}$ : 목옆점 허리둘레선길이 $+0.3 \mathrm{~cm}$ 에서 바깥 으로 $3 \mathrm{~cm}$ 나가서 $\mathrm{N}$ 점 표시한다.

(11) $\mathrm{N} \sim \mathrm{O}$ : 옆길이만큼 선을 그린다. $\mathrm{H} \sim \mathrm{L} \sim \mathrm{O}$ 를 연결 하여 곡선을 그린다. 이 선이 진동둘레선이 된 다.

(12) B P: $7.5 \mathrm{~cm}$ 표시한다.

(13) $\mathrm{N} \sim \mathrm{Q}$ : 허리앞둘레 $+0.6 \mathrm{~cm}-\mathrm{B} \sim \mathrm{P}, \mathrm{Q} \sim \mathrm{P}$ 는 다트량이 된다. $\mathrm{I}$ 에서 $1.6 \mathrm{~cm}$ 내린 점과 $\mathrm{Q}, \mathrm{P}$ 가 연결된 선 이 다트선이 된다.

Back

(1) A B: 목옆점에서 허리둘레선길이의 선을 그린 다.

(2) $\mathrm{A} \mathrm{C}$ : 어깨가쪽사이길이 $/ 2$ 의 선을 그린다. $\mathrm{C}$ 에
서 약 $8 \mathrm{~cm}$ 의 수직선을 그린다.

(3) B D: 뒷젖가슴둘레 $/ 2+2$ 의 선을 그린다. $\mathrm{D}$ 에서 약 $28 \mathrm{~cm}$ 의 수직선을 그린다.

(4) $\mathrm{A} \sim \mathrm{E}: 2.3 \mathrm{~cm}$ 에 표시한다.

(5) A F: 목밑둘레 $/ 6+0.5 \mathrm{~cm}$ 에 표시한다.

(6) $\mathrm{E}$ 에서 약 $2 \mathrm{~cm}$ 직각 유지하면서 $\mathrm{F}$ 와 연결되는 곡선을 그린다.

(7) $\mathrm{B} \sim \mathrm{G}$ : 어깨경사 $+0.3 \mathrm{~cm}$ 의 선을 그린다. $\mathrm{F} \sim \mathrm{H}$ 는 앞어깨길이 $+1.3 \mathrm{~cm}$ 를 그린다.

(8) $\mathrm{B} \sim \mathrm{K}$ :허리뒤둘레 $/ 2+4 \mathrm{~cm}$ (다트분량) $+0.6 \mathrm{~cm}$ (여유 분량)

(9) $\mathrm{K} \sim \mathrm{L}$ : 수직으로 $0.5 \mathrm{~cm}$ 내려 그린다.

(10) $\mathrm{B} \sim \mathrm{M}$ : 앞판의 $\mathrm{B} \sim \mathrm{P}$ 와 같은 길이에 표시한다.

(11) $\mathrm{M} \sim \mathrm{N}: 4 \mathrm{~cm}$ 에 표시하고, 그 중심에 $\mathrm{O}$ 를 표기하 여 다트의 중심선을 그린다.

(12) $\mathrm{O} \sim \mathrm{P}$ : 진동선 $+2 \mathrm{~cm}$ 에 표시하고, $\mathrm{M}, \mathrm{N}$ 과 연결한 다.

(13) $\mathrm{L} \sim \mathrm{Q}$ : 앞판의 $\mathrm{N} \sim \mathrm{O}$ 와 같은 길이에 표시한다.

(14) $\mathrm{R}: \mathrm{F} \sim \mathrm{H}$ 의 $1 / 2$ 점에 표시한다.

(15) R S: R P까지 가이드라인을 그리고, $7.5 \mathrm{~cm}$ 점 에 $\mathrm{S}$ 를 표시한다. T점, $\mathrm{U}$ 점을 연결한다.

(16) $\mathrm{I} J$ : $\mathrm{E} \sim \mathrm{B}$ 를 $1 / 4$ 등분하여 겨드랑뒷벽사이길이 $12+0.6 \mathrm{~cm}$ 의 수평선을 그리고 J표기 후 $10 \mathrm{~cm}$ 의 가이드라인을 수직으로 그린다.

(17) $\mathrm{H} \sim \mathrm{J} \sim \mathrm{Q}: \mathrm{H}, \mathrm{J}, \mathrm{Q}$ 를 연결하여 곡선을 그린다.

(18) 앞뒤판 허리다트 닫은 상태에서 옆선끼리 마주 대고 곡선의 허리둘레선을 한번에 그려서 마무 리한다. 진동둘레선도 확인한다.

(19) 어깨선을 마주 대고 앞뒤판 목둘레선과 진동둘 레선을 확인한다.

\section{(2) Drafting the basic kimono sleeve} preparation process

(1) 상의원형 뒤판 $\mathrm{a} \sim \mathrm{b}$ 에 절개선을 넣고, 어깨다트 $\mathrm{T} \sim \mathrm{U}$ 를 닫는다. 진동둘레에 생기는 다트량은 여 유분으로 남겨둔다.

(2) 상의원형 앞판 패턴을 잘라내고, $\mathrm{a}, \mathrm{b}, \mathrm{c}$ 에 절개 선을 넣는다.

\section{Drafting}

(3) C: 상의원형 뒤판의 어깨가쪽점에서 $0.6 \mathrm{~cm}$ 올 
린 점

(4) $\mathrm{D} \sim \mathrm{C}: \mathrm{A} \sim \mathrm{B}$ 의 2 등분점 $\mathrm{D}$ 와 $\mathrm{C}$ 를 연결하여 $\mathrm{C}$ 에 서 소매길이만큼 직선을 그린다.

(5) E F: E에서 직각선을 내려 손둘레의 $1 / 2$ 만큼 그린다.

(6) $\mathrm{G} \sim \mathrm{H}: 1 \mathrm{~cm}$ 옆선의 연장선을 그리고, $\mathrm{F}$ 와 $\mathrm{H}$ 를 연결한다. 측정한 치수에 따라 위팔둘레선, 팔 꿈치둘레선을 그린다.

(7) 뒤판 패턴 위에 상의원형 앞판 패턴을 올려놓 고, 어깨가쪽점에 핀을 꽂아 고정한다.

(8) 진동둘레의 절개선을 벌리고, 허리다트는 닫으 면서 앞판의 옆선이 뒤판의 옆선과 만나도록 한 다.

(9) I, J: E에서 $0.5 \mathrm{~cm}$ 내려서 I를 표시하고, E에서 $0.5 \mathrm{~cm}$ 올려서 $\mathrm{J}$ 를 표시한다.

(10) $\mathrm{C} \mathrm{I}$ : 앞판의 소매중심선이 된다.

(11) $\mathrm{C} \mathrm{J}$ : 뒤판의 소매중심선이 된다.

이상과 같이 수정, 보완하여 개발한 연구원형은 〈Fig. 5〉, 〈Fig. 6〉과 같고 연구원형과 최종연구원형 간의 패턴 차이를 확인할 수 있는 패턴의 중첩도는 〈Fig. 7〉과 같다.

\section{2) Appearance evaluation and mobility evaluation}

최종연구원형의 외관평가는 평가의 정확성을 위해 평가자 8 명 또한 1 차 수집원형 평가와 동일하게 구성 하여 시행하였다. 피험자와 평가항목, 평가방법은 1

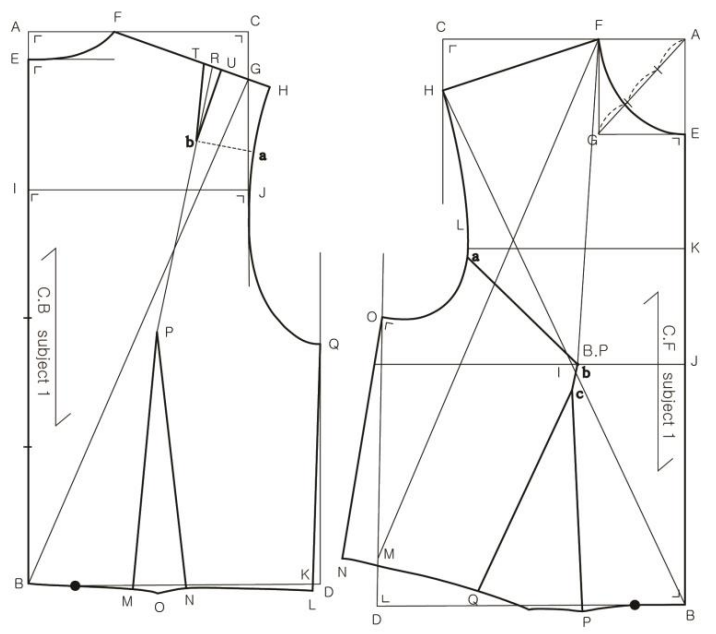

<Fig. 5> Final research basic bodice
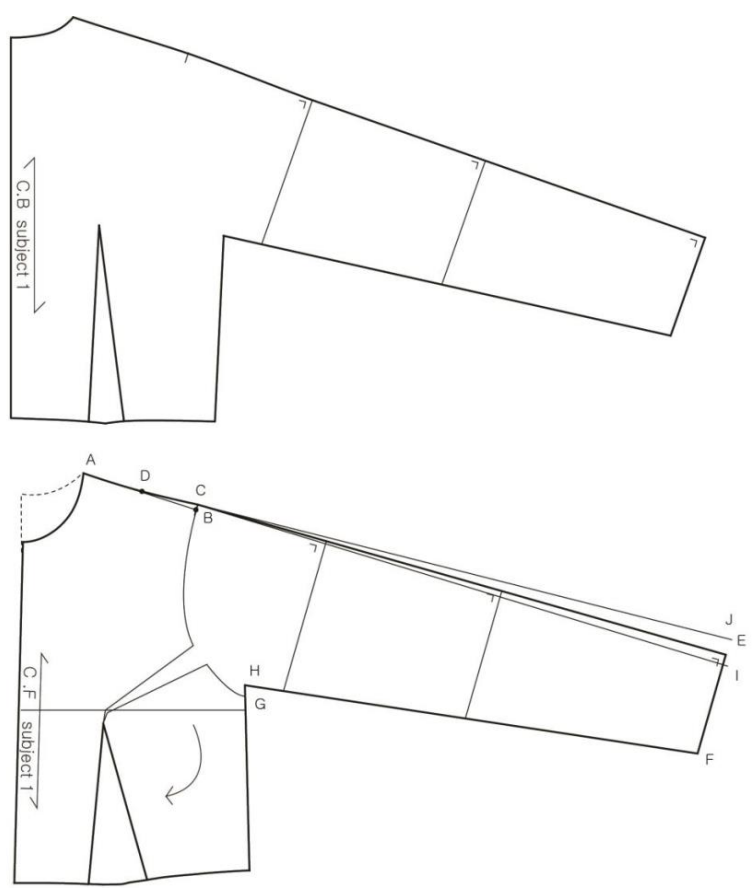

<Fig. 6> Final research basic kimono sleeve

차 수집원형 외관평가와 같다. 동작평가 역시 1 차 수 집원형 동작평가와 동일한 방법으로 시행하였다. 연 구원형과 최종연구원형의 외관평가 자세는 〈Fig. 8>과 같다.

\section{Result and Discussion}

이상과 같이 살펴본 결과, 외관평가 전면 12 항목의 전체 평균은 최종연구원형이 4.21점으로 연구원형 3.29점보다 높은 것으로 나타났으며, 통계적으로 유 의미한 차이가 있는 것으로 나타났다 $(p<.001)$. 측면 10 항목의 전체 평균은 최종연구원형이 4.34점으로 연구 원형 2.89점보다 높은 것으로 나타났으며, 통계적으 로 유의미한 차이가 있는 것으로 나타났다 $(p<.001)$. 후 면 8항목의 전체 평균 또한 최종연구원형이 4.00 점으 로 연구원형 3.00점보다 높은 것으로 나타났으며, 통 계적으로 유의미한 차이가 있는 것으로 나타났다 $(p<$ .001). 전체 평균은 최종연구원형이 4.19점으로 연구 원형 3.08 점보다 높은 것으로 나타났으며, 통계적으 로 유의미한 차이가 있는 것으로 나타났다 $(p<.001)$. 이 처럼 전면, 측면, 후면 평균 모두 최종연구원형이 연 구원형보다 높은 점수를 보인 것을 알 수 있다(Table 5). 


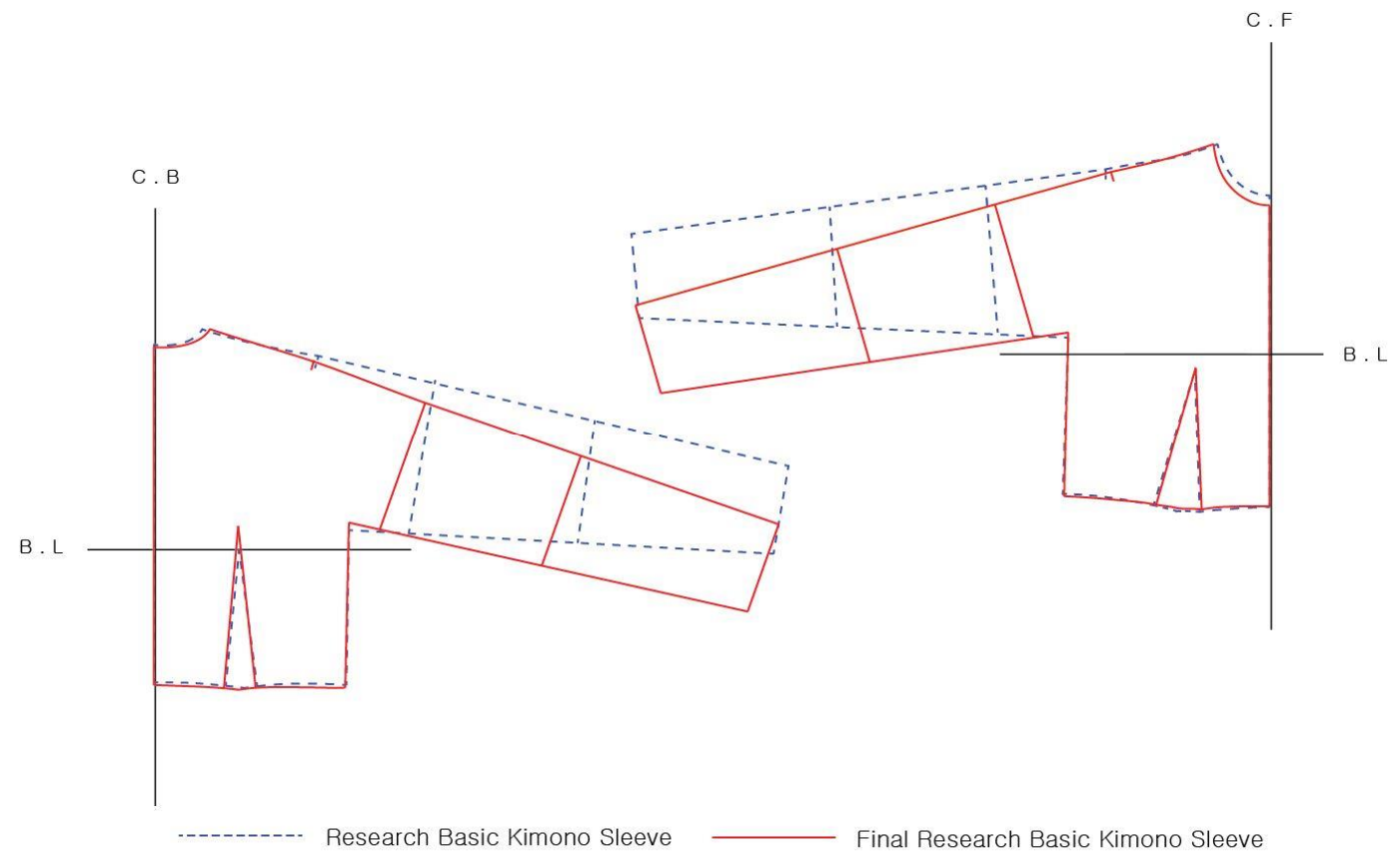

<Fig. 7> Overlapping of research basic kimono sleeve and final research basic kimono sleeve

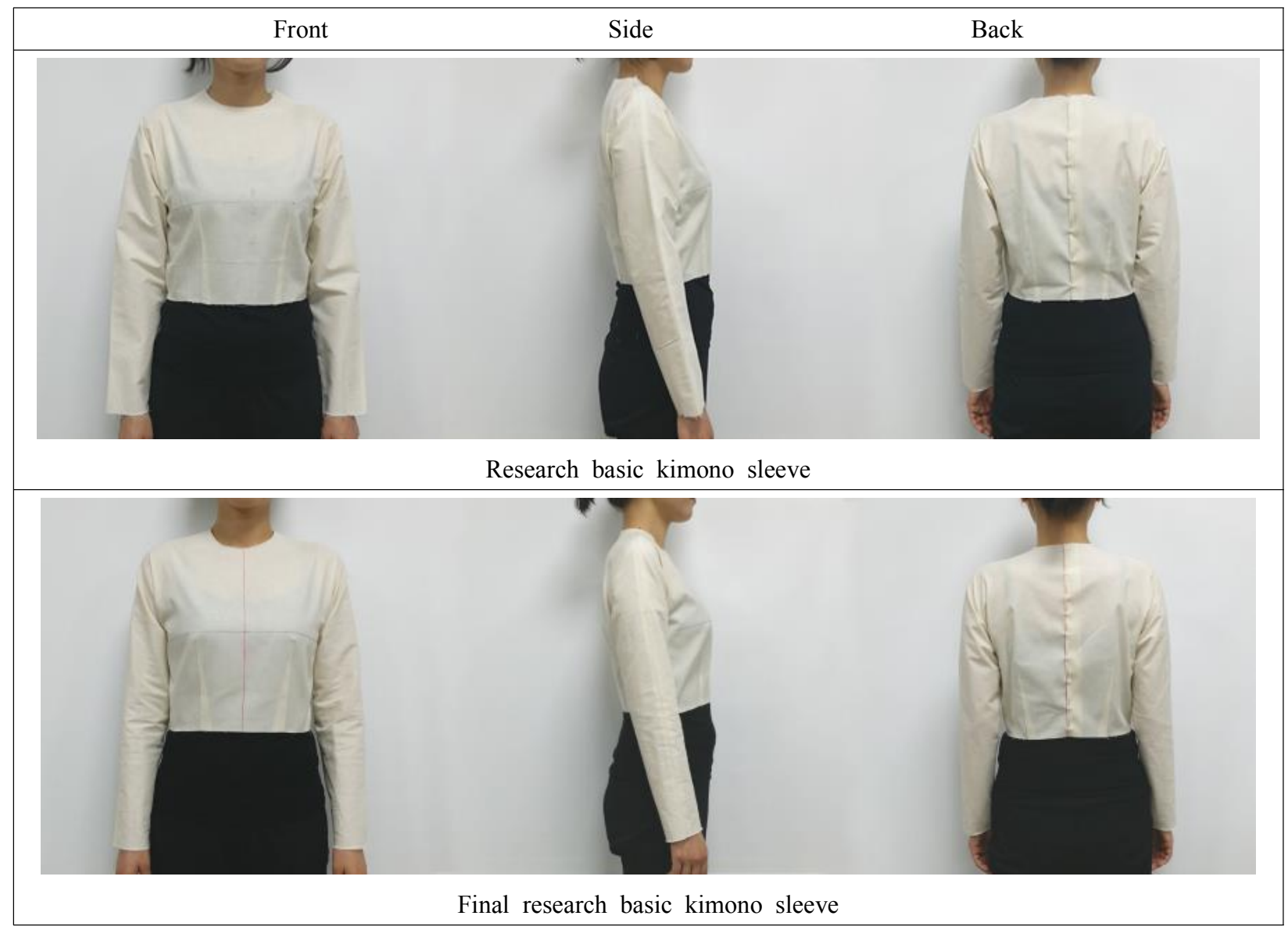

<Fig. 8> Comparison of appearance evaluation of research basic kimono sleeve and final research basic kimono sleeve appearance evaluation 
$<$ Table 5> Results of comparison of appearance evaluation of research basic kimono sleeve and final research basic kimono sleeve appearance evaluation

\begin{tabular}{|c|c|c|c|}
\hline \multirow{2}{*}{ Evaluation items } & \multicolumn{2}{|c|}{$M(S D)$} & \multirow{2}{*}{$t$-value } \\
\hline & Research basic kimono sleeve & Final research basic kimono sleeve & \\
\hline \multirow{2}{*}{ Front } & 3.29 & 4.21 & \multirow{2}{*}{$-11.138^{* * *}$} \\
\hline & $(0.487)$ & $(0.501)$ & \\
\hline \multirow{2}{*}{ Side } & 2.89 & 4.34 & \multirow{2}{*}{$-17.086^{* * *}$} \\
\hline & $(0.586)$ & $(0.417)$ & \\
\hline \multirow{2}{*}{ Back } & 3.00 & 4.00 & \multirow{2}{*}{$-11.120^{* * *}$} \\
\hline & $(0.581)$ & $(0.495)$ & \\
\hline \multirow{2}{*}{ Whole average } & 3.08 & 4.19 & \multirow{2}{*}{$-15.217^{* *}$} \\
\hline & $(0.468)$ & $(0.411)$ & \\
\hline
\end{tabular}

${ }^{*} p<.05, \quad{ }^{* *} p<.01, \quad{ }^{* * *} p<.001$

<Table 6> Results of comparison of appearance evaluation of research basic kimono sleeve and final research basic kimono sleeve mobility evaluation

\begin{tabular}{|c|c|c|c|}
\hline \multirow{2}{*}{ Evaluation items } & \multicolumn{2}{|c|}{$M(S D)$} & \multirow{2}{*}{$t$-value } \\
\hline & Research basic kimono sleeve & Final research basic kimono sleeve & \\
\hline \multirow{2}{*}{ Erect posture } & 4.10 & 4.77 & \multirow{2}{*}{$-3.255^{*}$} \\
\hline & $(0.608)$ & $(0.087)$ & \\
\hline \multirow{2}{*}{ Forward $45^{\circ}$} & 4.14 & 4.78 & \multirow{2}{*}{$-3.970^{* *}$} \\
\hline & $(0.429)$ & $(0.216)$ & \\
\hline \multirow{2}{*}{ Forward $90^{\circ}$} & 4.25 & 4.59 & \multirow{2}{*}{$-2.466^{*}$} \\
\hline & $(0.383)$ & $(0.133)$ & \\
\hline \multirow{2}{*}{ Aside $45^{\circ}$} & 4.29 & 4.98 & \multirow{2}{*}{$-3.870^{*}$} \\
\hline & $(0.539)$ & $(0.048)$ & \\
\hline \multirow{2}{*}{ Aside $90^{\circ}$} & 4.24 & 4.78 & \multirow{2}{*}{$-2.707^{*}$} \\
\hline & $(0.585)$ & $(0.126)$ & \\
\hline \multirow{2}{*}{ Walking } & 3.90 & 4.68 & \multirow{2}{*}{$-2.485^{*}$} \\
\hline & $(0.929)$ & $(0.139)$ & \\
\hline \multirow{2}{*}{ Whole average } & 4.15 & 4.76 & \multirow{2}{*}{$-3.208^{*}$} \\
\hline & $(0.571)$ & $(0.042)$ & \\
\hline
\end{tabular}

${ }^{*} p<.05, \quad{ }^{* *} p<.01, \quad{ }^{* * *} p<.001$

동작평가 정립 시 10 항목의 전체 평균은 최종연구 원형이 4.77점으로 연구원형 4.10점보다 높은 것으로
나타났으며, 통계적으로 유의미한 차이가 있는 것으 로 나타났다 $(p<.05)$, 팔을 앞으로 $45^{\circ}$ 들었을 때 7 항 
목의 전체 평균은 최종연구원형이 4.78점으로 연구원 형 4.14점보다 높은 것으로 나타났으며, 통계적으로 유의미한 차이가 있는 것으로 나타났다 $(p<.01)$. 팔을 앞으로 $90^{\circ}$ 들었을 때 7항목의 전체 평균은 최종연 구원형이 4.59점으로 연구원형 4.25점보다 높은 것으 로 나타났으며, 통계적으로 유의미한 차이가 있는 것 으로 나타났다 $(p<.05)$. 팔을 옆으로 $45^{\circ}$ 들었을 때 7 항목의 전체 평균은 최종연구원형이 4.98점으로 연구 원형 4.29점보다 높은 것으로 나타났으며, 통계적으 로 유의미한 차이가 있는 것으로 나타났다 $(p<.01)$. 팔 을 옆으로 $90^{\circ}$ 들었을 때 7항목의 전체 평균은 최종 연구원형 4.78점으로 연구원형 4.24점보다 높은 것으 로 나타났으며, 통계적으로 유의미한 차이가 있는 것 으로 나타났다 $(p<.05)$. 걸을 때 7 항목의 전체 평균은 최종연구원형이 4.68점으로 연구원형 3.90점보다 높 은 것으로 나타났으며, 통계적으로 유의미한 차이가 있는 것으로 나타났다 $(p<.05)$. 연구원형과 최종연구 원형의 전체 평균 결과, 최종연구원형이 4.76점으로 나타나 연구원형 4.15점보다 높은 것으로 나타났으 며, 통계적으로 유의미한 차이가 있는 것으로 나타났 다 $(p<.05)$ (Table 6).

이상과 같이 1 차 수집원형 패턴 착의평가에서 선 정된 연구원형 패턴을 수정, 보완하여 최종연구원형 패턴을 개발하여 2 차 착의평가한 후 연구원형과 최종 연구원형을 비교, 분석하였다. 그 결과 외관평가에서 최종연구원형 4.19점, 연구원형 3.08점으로 연구원형 이 높은 것으로 나타났고, 동작평가에서 최종연구원 형 4.76점, 연구원형 4.15점으로 최종연구원형이 높 은 것으로 나타났다. 이처럼 개발된 최종연구원형은 맞음새와 착용감에서 모두 연구원형보다 높은 것으 로 나타났음을 알 수 있다.

\section{Conclusion and Suggestion}

본 연구는 현대 패션에서 디자인 모티브로 지속적 으로 나타나고 있으며, 최근 그 경향이 두드러지는 기모노슬리브를 연구의 주제로 하여 선행연구에서 다루어지지 않았던 국내 체형에 따른 기모노슬리브 원형을 개발하였다는 점에서 그 의의를 가진다. 이상 과 같이 수정된 원형의 2 차 착의평가 결과, 외관평가 전체 항목의 평균은 최종연구원형이 4.19점으로 연구
원형 3.08점보다 높은 것으로 나타났으며 모든 항목 에서 통계적으로 유의미한 차이가 있는 것으로 나타 났다 $(p<.001)$. 동작평가 전체 항목의 평균 또한 최종 연구원형이 4.76점으로 나타나 연구원형 4.15점보다 높은 것으로 나타났으며, 통계적으로 유의미한 차이 가 있는 것으로 나타났다 $(p<.001)$. 이상과 같이 1 차 수집원형 착의평가에서 선정된 연구원형을 수정, 보 완하여 최종연구원형을 개발하였고, 2 차 착의평가한 후 연구원형과 최종연구원형을 비교, 분석하였다. 그 결과, 개발된 최종연구원형은 맞음새와 착용감에서 모 두 연구원형보다 높은 것으로 나타났음을 알 수 있다.

이상과 같이 기모노슬리브 원형패턴의 경우, 어깨 경사 각도가 높거나 위팔둘레가 넓다고 착용감이 좋 아진다고 설명할 수는 없으며, 착용감에 영향을 미치 는 부분 즉, 겨드랑점(진동깊이)의 위치, 적당한 팔둘 레와 진동의 여유분, 어깨경사각 등이 이상적으로 적 용될 때 착용감을 최적화하는 동시에 시각적으로 이 상적인 외관을 유지할 수 있음을 확인할 수 있었다.

마지막으로 패션디자인에 있어 디자인이 구체화되 어 완성되기 위해서는 정확하고 감각적인 원형 구성 을 통해 다양한 디자인이 이상적으로 구현될 수 있음 을 인지하고, 그에 따른 원형 패턴 개발에 대한 다양 한 후속 연구를 기대한다.

\section{References}

Armstrong, H. J. (2010). Patternmaking for fashion design (5th ed.). Upper Saddle River, NJ: Prentice Hall.

Cho, H. S. (1993). Kimono sleeve의 기능성에 관한 연구 [The study on the functionality of Kimono Sleeve]. Unpublished master's thesis, Sungshin Women's University, Seoul, Korea.

Hong, S.-T. (2003). The study on movement suitability and aesthetics of kimono sleeve: Focusing on the early 20's maiden. Journal of Daegu Polytechnic College, 17, 297-307.

$\mathrm{Im}, \mathrm{W}$. J. (2003). 의복구성학: 설계 및 봉제 (Rev. ed.) [Pattern making]. Seoul: Gyomoonsa.

Kim, A.-R. (1983). 어깨의 경사각별에 따른 Kimono Sleeve Pattern 제작에 관한 연구 [Untersuchung 
des Aermelschnitts fuer Kimonos im Bezug auf den Neigungswinke der Schulter]. Journal of the Humanities, 12, 231-246.

Kim, K. S. (1998). Patternmaking. Seoul: Kyohakyungusa.

Kim, O. K. (1988). A study on the kimono sleeve pattern: The sleeve's cap angle, the ease of bust, sleeve width. Unpublished master's thesis, Sungkyunkwan University, Seoul, Korea.

Kim, S. Y. (1996). A study on sleeve slant and development of gusset drafting method of kimono sleeve pattern. Seoul National University, Seoul, Korea.

Kopp, E., Rolfo, V., Zelin, B., \& Gross, L. (1991). How to draft basic patterns (4th ed.). New York: Fairchild Fashion \& Merchandising Group.
Kopp, E., Rolfo, V., Zelin, B., \& Gross, L. (1992). Designing apparel through the flat pattern (6th ed.). New York: Fairchild Fashion \& Merchandising Group.

Kwon, S. K., Jeong, J. C., \& Park, S. K. (2013). A study on the sleeve angles and gusset for the improvement of movability in a basic Kimono sleeve: Focusing on the standard body type in their thirties. The Research Journal of the Costume Culture, 21(5), 742-754. doi:10.7741/rjcc. 2013.21.5.742

Size Korea. (n.d.). Standard body type. Retrieved April 20, 2015, from https://sizekorea.kr/05_application/bodyFormCategory1_1.asp?OlapCode=SI ZU050101 